\title{
Scholars and Literati at the Old University of Aberdeen $(1495-1800)$
}

\author{
David de la Croix Hugo Jay \\ IRES/LIDAM, UCLouvain
}

This note is a summary description of the set of scholars and literati who taught at the Old University of Aberdeen, also called King's College, from its inception in 1495 to the eve of the Industrial Revolution in 1800.

\section{The UnIVERsity}

The Old University of Aberdeen, King's College, was founded in 1495 by the archbishop of the city, William Elphinstone, who was also professor in Canon Law at the Universities of Paris, Orléans and Glasgow. The Papal Bull granting the rights to the university was issued by Pope Alexander VI. In his survey of medieval universities, Rashdall claims that one important purpose was to bring civilization to the highland clergy, whose extreme ignorance was appalling (Rashdall 1895). The University remained Catholic for a while, but became Protestant with the Scottish Reformation in 1560. It is among the most ancient Anglo-Saxon universities, and the third oldest university in Scotland after St-Andrews and Glasgow. This note is limited to describing some statistics on its members. The New University of Aberdeen, Marischal College, was founded in 1593, using the building of the monastic orders dispossessed by the Reformation (Herbermann 1913), hence becoming Aberdeen's second university. The two colleges merged through the Universities Act of 1858 to form the modern University of Aberdeen. Traditionally, Medicine and Law were taught at Marischal and Arts and Divinity at King's College.

\section{SOURCES}

In a book published in 1893 . Peter John Anderson lists the professors, rectors, and other members of the academic staff of King's College. Our sample of members of the University is likely quite complete, but unfortunately Anderson (1893) provides little biographic information on the listed people.

\section{SOME STATISTICS}

Table 1 shows some descriptive statistics. We found 197 scholars and literati. Unfortunately, we do not know them well. The year of birth is known for $29.4 \%$ of them, with an improvement in this percentage only in the last period. The mean age at nomination is 35.8 years. Longevity (mean age at death \& expected age at death when 30 ) has normal values, but computed on very small samples. The birth place is known for only $20.3 \%$ of the individuals. The median distance between birth and Aberdeen is $25 \mathrm{~km}$. This median was higher when the university was created. Finally, $16.8 \%$ of the scholars have a Wikipedia page (in some language), and $25.4 \%$ of them have left a footprint in the catalogues of the libraries of the world, Worldcat, either by having published some work, or by having been the subject of published books and articles. These two percentages indicate that among the obscure teachers, there were some renowned persons. 


\begin{tabular}{|c|c|c|c|c|c|c|}
\hline \multicolumn{2}{|c|}{ Period } & \multirow{2}{*}{$\begin{array}{l}\text { nb. } \\
\text { obs }\end{array}$} & \multirow{2}{*}{$\begin{array}{l}\% \text { birth year } \\
\text { known }\end{array}$} & \multirow{2}{*}{$\begin{array}{l}\text { mean age } \\
\text { at nomin. }\end{array}$} & \multirow{2}{*}{$\begin{array}{l}\text { mean age } \\
\text { at death }\end{array}$} & \multirow{2}{*}{$\begin{array}{l}\text { exp. age } \\
\text { at death }\end{array}$} \\
\hline Start & End & & & & & \\
\hline 1450 & 1526 & 16 & 25 & 32.7 & 69 & 65.3 \\
\hline 1527 & 1617 & 71 & 22.5 & 32.6 & 65.9 & 66.1 \\
\hline 1618 & 1685 & 54 & 29.6 & 36.6 & 68.7 & 71.3 \\
\hline 1686 & 1733 & 30 & 26.7 & 45 & 73.7 & 69.6 \\
\hline 1734 & 1800 & 26 & 53.8 & 32.4 & 65.4 & 61.6 \\
\hline \multirow[t]{2}{*}{1200} & 1800 & 197 & $29 . \overline{4}$ & 35.8 & $6 \overline{7} . \overline{8}$ & 66.3 \\
\hline & & & $\begin{array}{c}\text { \% birth place } \\
\text { known }\end{array}$ & $\begin{array}{l}\text { median distance } \\
\text { birth-institution }\end{array}$ & $\begin{array}{c}\% \text { with } \\
\text { Wikipedia }\end{array}$ & $\begin{array}{c}\% \text { with } \\
\text { Worldcat }\end{array}$ \\
\hline 1450 & 1526 & & 18.8 & 93 & 25 & 25 \\
\hline 1527 & 1617 & & 9.9 & 0 & 9.9 & 15.5 \\
\hline 1618 & 1685 & & 20.4 & 0 & 18.5 & 29.6 \\
\hline 1686 & 1733 & & 23.3 & 78 & 13.3 & 16.7 \\
\hline 1734 & 1800 & & 46.2 & 25 & 30.8 & 53.8 \\
\hline 1000 & 1800 & & $20 . \overline{3}$ & 25 & $1 \overline{16} . \overline{8}$ & 25.4 \\
\hline
\end{tabular}

Table 1: Summary statistics by period

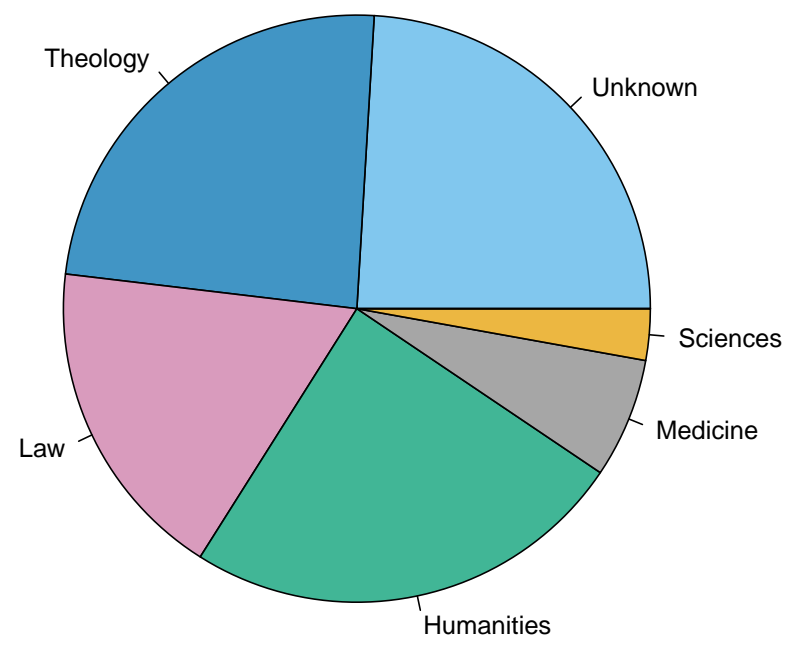

Figure 1: Broad fields at the Old University of Aberdeen 


\section{FIELDS}

Figure 1 shows the relative importance of broadly defined fields. The figure shows the predominance of three fields: law, humanities, and theology. The University was originally intended to train teachers, clergy, lawyers, and administrators for the Scottish Crown. The prevalence of these fields is therefore not surprising. On the other hand, despite the very early establishment of the Chair of Medicine (1497), the field remains poorly represented. This could be due to the late development of the faculty. In the important "unknown" category, we find mainly the rectors of the University who, for the majority, did not have another clear function.

\section{Places OF BIRTh}

Figure 2 is a plot of the places of birth of all the scholars of the old University of Aberdeen. The basin of recruitment is not just limited to the British Isles, but almost to Scotland alone.

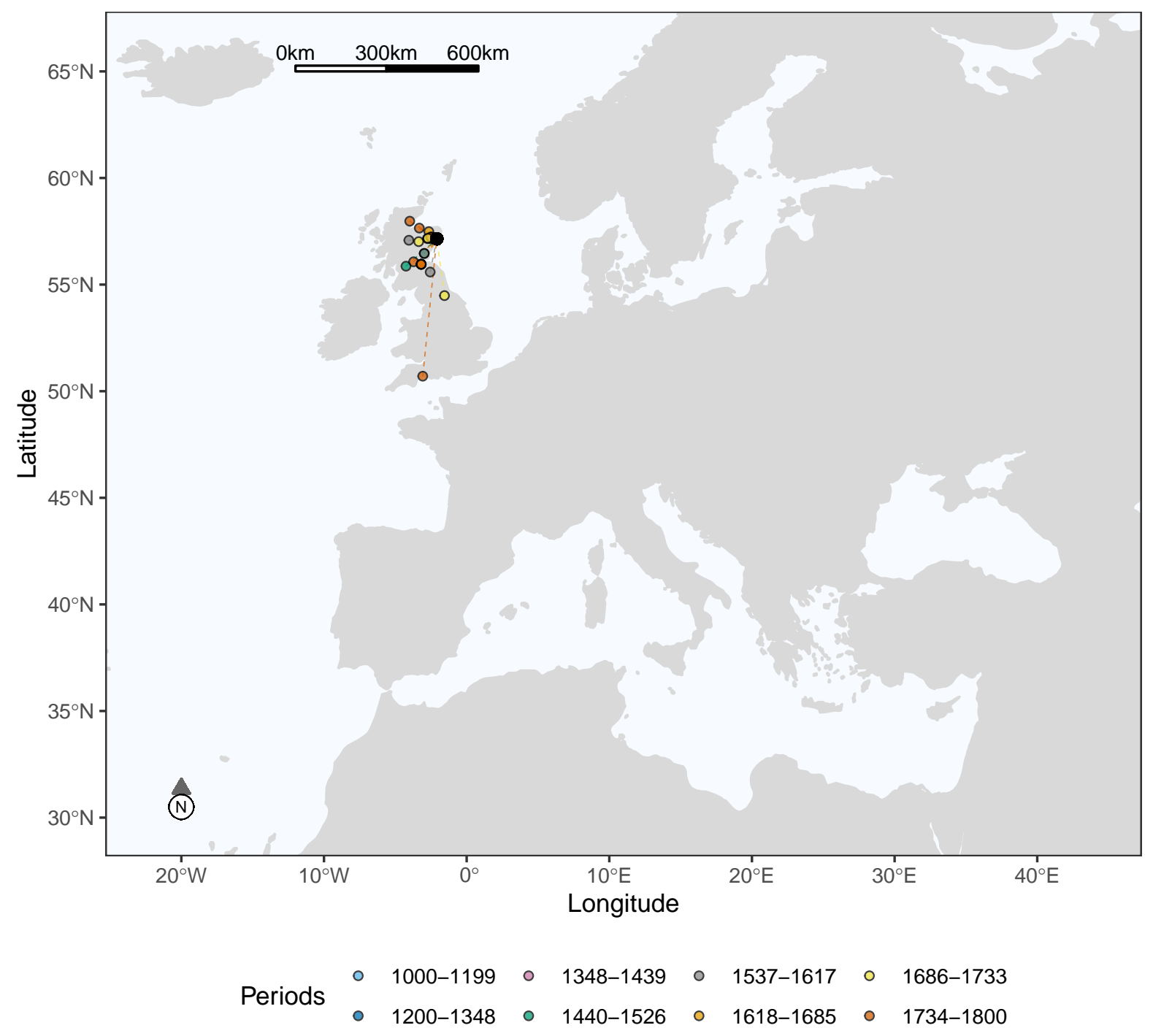

Figure 2: Places of birth of the scholars and literati at the Old University of Aberdeen 


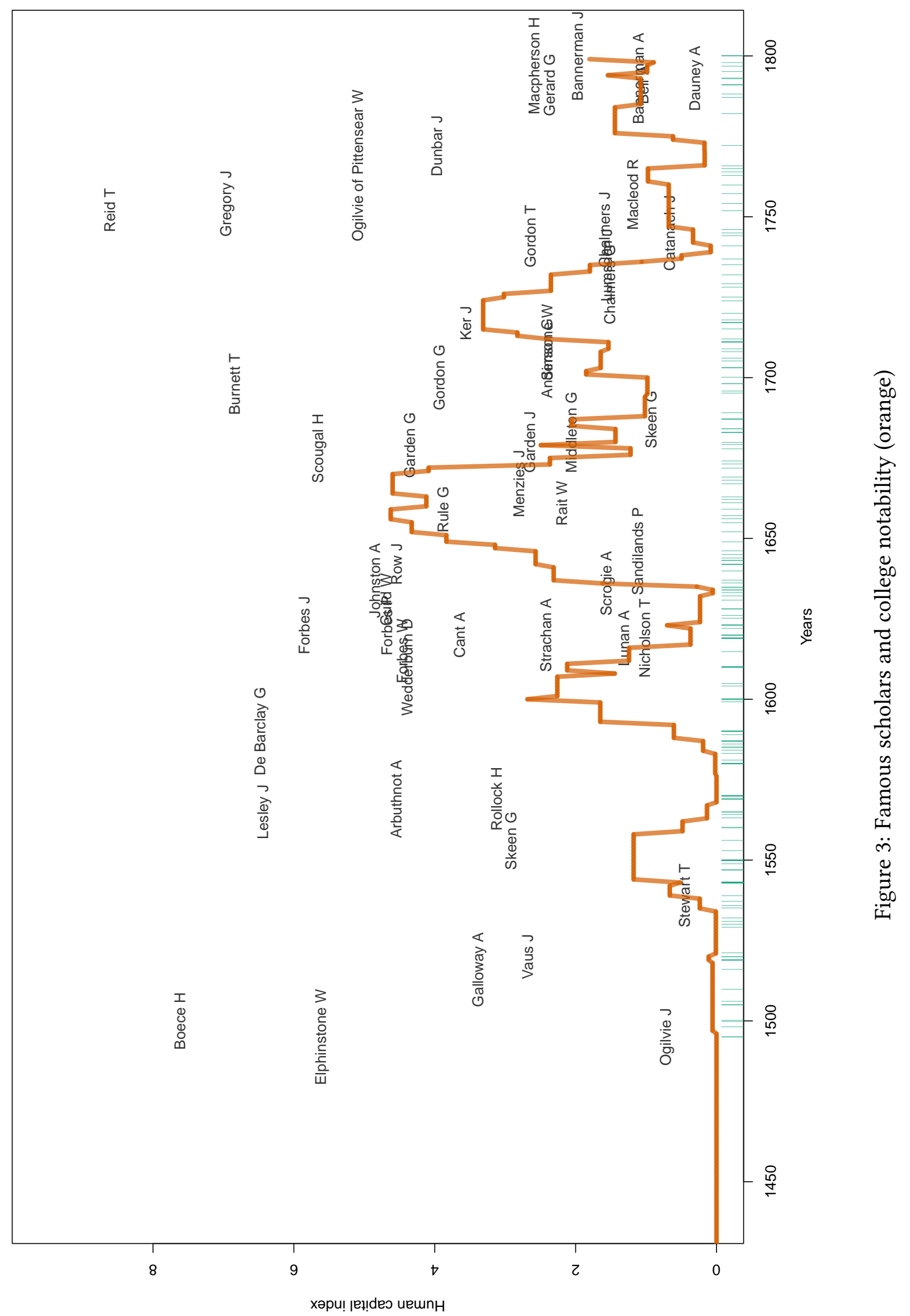




\section{HUMAN CAPITAL OF SCHOLARS AND LITERATI}

For each person in the database, we compute a heuristic human capital index, identified by combining information from Worldcat and Wikipedia using principal component analysis. We also compute the notability of the university at each date by averaging the human capital of the scholars active at the old University of Aberdeen 25 years before that date. Details are given in the Appendix. Figure 3 shows the names of all the scholars with a positive human capital index. The orange line plots the notability of the university.

The old University of Aberdeen experienced waves of notability, driven by some professors who published very well and were widely recognized. The pattern appears random; there are clear phases of rise and decline, except perhaps in the eighteenth century, where notability is at its lowest level.

\section{TOP 6 PROFESSORS}

We now provide a brief overview of the six professors with the highest human capital index.

Thomas Reid (Strachan 1710 - Glasgow 1796) was a Scottish philosopher. He is considered the founder of the Scottish School of Common Sense. Professor of philosophy at King's College from 1752 to 1764, he created the Aberdeen Philosophical Society which brought together most of the intellectuals from the two nearby colleges, King's and Marischal. His work shifted the center of the thought of his century. While remaining faithful to a philosophy of conscience, he shifted towards a doctrine in which the community, rather than the individual, was the authority holding the truth.

Hector Boece (Dundee 1465 - Aberdeen 1536) was a Scottish historian, writer, and philosopher. A professor of philosophy at the University of Paris, he left the French capital when, in 1500, he received a generous offer to become the first Principal of King's College in Aberdeen. Working with William Elphinstone, he structured the university along the lines of Paris and Orleans. He remained head of the College until his death in 1536.

John Gregory (1724 Aberdeen - 1773 Edinburgh) was a Scottish physician, writer and philosopher. After studying medicine in Edinburgh and Leiden (United Provinces), he returned to his native city to teach philosophy at King's College. Very concerned by medical ethics, he participated in the elaboration of the first rules of medical ethics in Great Britain. He published a series of lectures in 1770, in which the scientific philosophy of Francis Bacon was mixed with a moral philosophy centered on the subject.

Guillaume de Barclay (1546 Aberdeen - 1608 Angers), also known as William Barclay, was a Scottish writer and lawyer. He began his studies at the University of Aberdeen before moving to France, where he studied law at the University of Bourges. He is known for his polemical work De potestate Papae: an et quatenus in reges et principes seculares ius et imperium habeat (published in 1609, after his death, translated in 1611 in "Of the Authoritie of the Pope: Whether and How Farre Forth He Hath Power and Authoritie over Temporall Kings and Princes"), where he opposes the usurpation of temporal powers by the pope.

John Leslie (1527 Scotland - 1596 Brussels) was a Scottish historian, bishop of the Catholic Church, and adviser to Mary Stuart. Leslie studied at the universities of Aberdeen, Paris, and Poitiers. From about 1554 he taught canon law at King's College, Aberdeen. When Mary Stuart returned to reign in Scotland in 1561, Leslie became her adviser. When Mary was imprisoned in England, he tried to help her and planned her escape. The plan failed and he was imprisoned in the Tower of London, where he began collecting material for his history of Scotland. Released and banished from England, he published his work in Rome in 1578 under the title De Origine, Moribus, et Rebus Gestis Scotorum (Concerning the origin, customs, and actions of the Scots in ten books). 
Thomas Burnett (1635-1715) was a British writer and theologian. His views and theories about the Earth made him a notable and controversial figure. He published the first part of his most famous work in 1681: Telluris Theoria Sacra, in which he described how the Earth would have been formed. He argued that before the Genesis flood the earth was an oval, fertile shape that was smooth and uniform. With the flood, oceans and mountains were formed as the surface of the earth fractured, releasing the underlying waters. Over time, the modern "corrupted" world was then created. His work attracted Newton's attention and earned him much criticism.

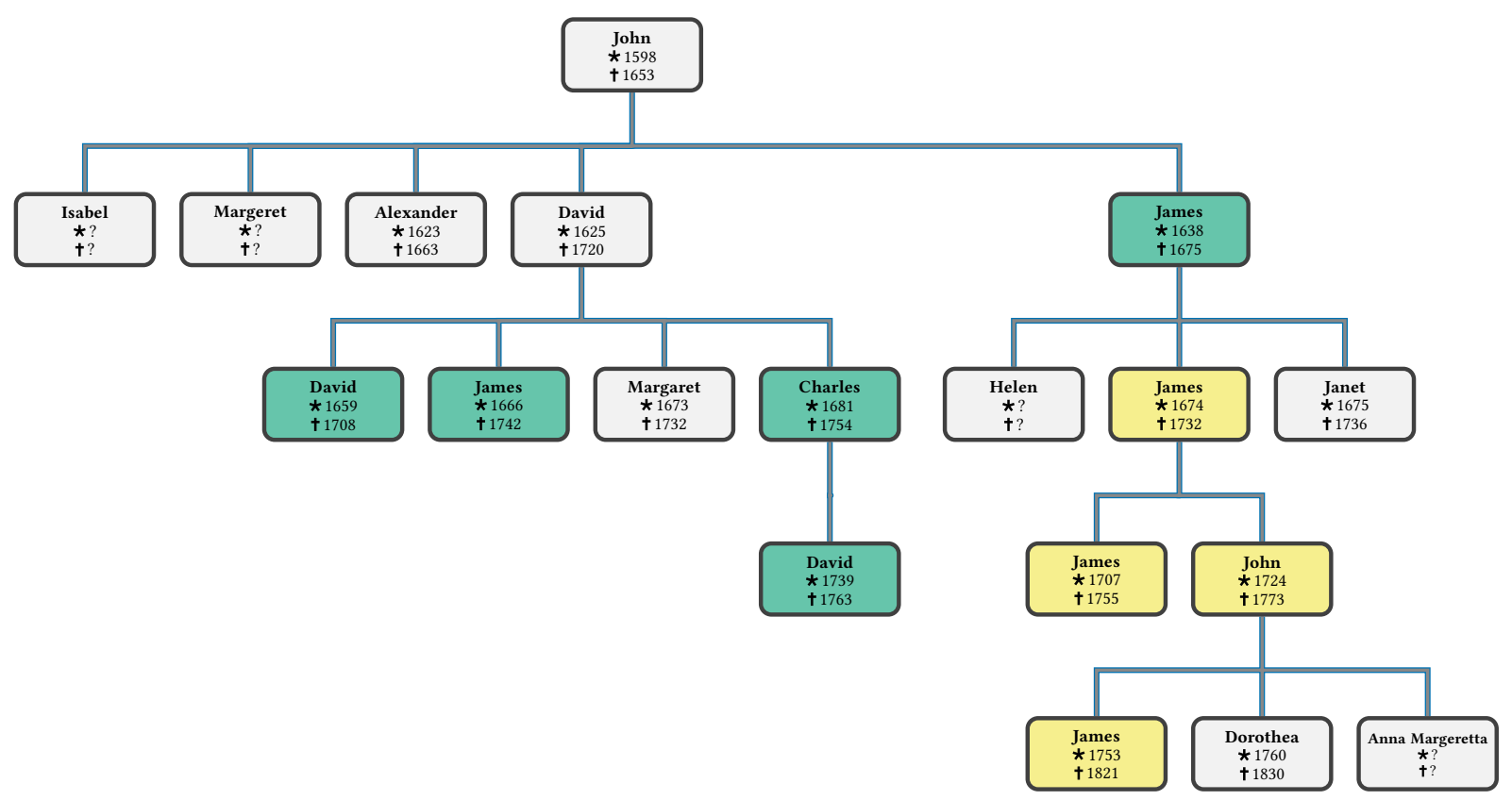

Figure 4: The Gregory family. Professors at the Old University of Aberdeen in yellow squares. Professors at other British universities in green squares.

\section{FAMILIES OF SCHOLARS}

We counted 9 father-son pairs among the professors at the Old University of Aberdeen.

Figure 4 gives one example of a family, the Gregorys (or Gregories). The ancestor, John, was educated at Marischal College before becoming Minister of Drumoak. To pay tribute to women who are too often hidden in academia, the website of the family http://www.gregorie.org/gregories/history/ professors.htm claims that "his wife Janet Anderson was a highly intelligent woman and there is little doubt that much of the genius of the later members of the family was inherited from her." According to www.geni.com and to the archives of the family at https://archiveshub.jisc.ac.uk/search/ archives/f9ffcc65-dd87-39e8-9bbe-26f4a3073338, they had three sons. Alexander of Finzeauch, M.A., born 1623, murdered by Francis Crichton, brother of Lord Frendraught, in 1663 ; David of Netherdale and Kinnairdy, librarian, King's College, 1625, died in 1720 ; James, M.A., inventor of the reflecting telescope, correspondent of Sir Isaac Newton, and Professor of Mathematics in Universities of St Andrews and Edinburgh. One of David's children, also named David, was a mathematician, astronomer, and professor at Edinburgh and Oxford universities. According to Wikipedia, David and his wife, Elizabeth Oliphant, had nine children, but seven died while still children. Another son of David, Charles (1681 - 1754) had a distinguished academic career at the University of St Andrews. Charles's son, also David Gregory (1712 - 1765), succeeded his father to the Chair of Mathematics at St Andrews, 1739 - 1763. David (1625-1720) lived to the great age of 95 and had the distinction of seeing three of his sons - David, James and Charles - all professors of mathematics at British universities at the same time. 
Going down the other branch of the family, James (1638-1675) had a son James (1674-1732) who taught medicine at the Old University of Aberdeen from 1725 to 1732. This James had two sons, John and James, who both taught medicine at Aberdeen. Finally, John had a son James (1753-1821), also professor of medicine.

\section{UNIVERSITY NETWORK}

Here, we assume that when a professor occupied a position in more than one university over his/her life, this established a link between those universities. The universities with which Aberdeen is linked are displayed in Figure 5 . It is striking to remark that, despite the very local basin of recruitment of the University we saw in Figure 2 there are international links. This arises because the Scottish members of Aberdeen University occupied positions abroad, either before coming back to Aberdeen, or after fleeing religious conflicts in their homeland.

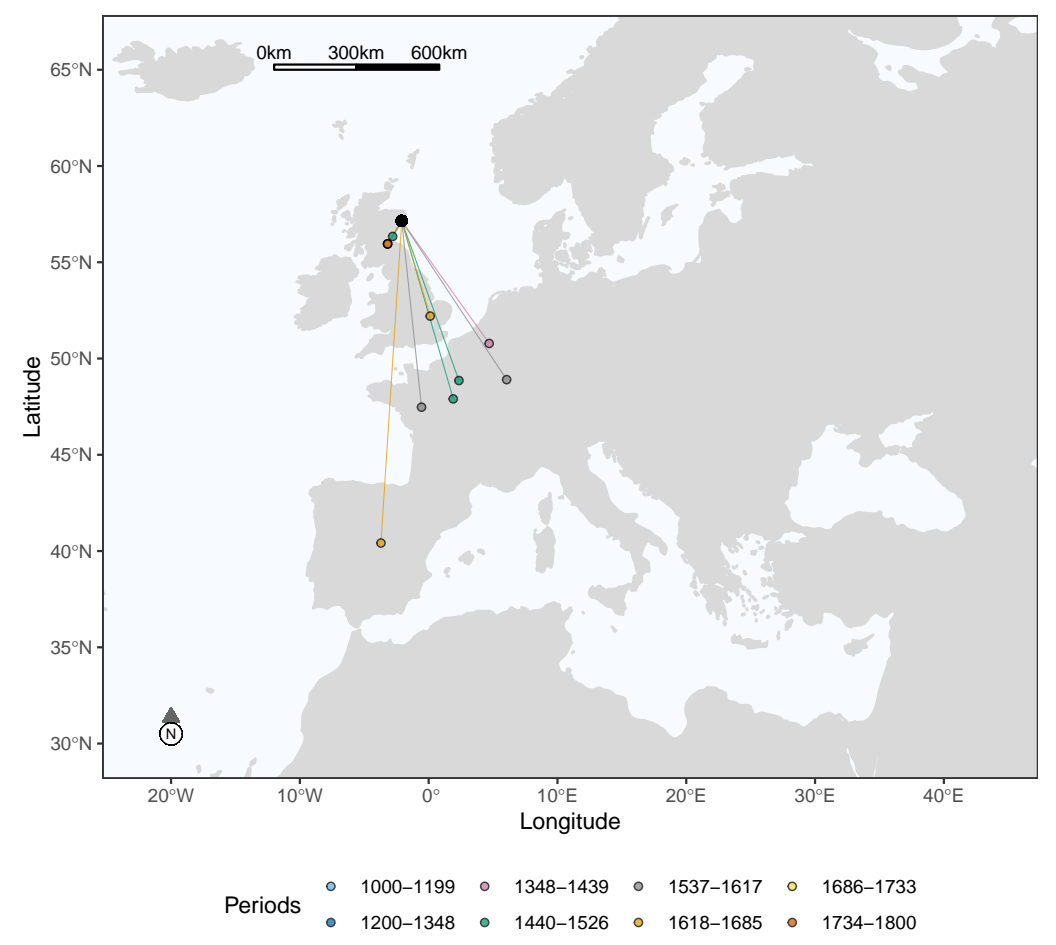

Figure 5: Links between the Old University of Aberdeen and other universities through scholars' mobility, by period

\section{AnecDotes}

The first university in Aberdeen, King's College, was founded because King James IV wanted to ensure that Scotland had as many universities as England.

The university was modelled on the University of Paris and intended principally as a school of arts, theology, canon and civil law. But in 1497, the College established the first chair of medicine in the English-speaking world. Even if the field was poorly represented for a long time, it was still the first and it might be why the university is nowadays top-ranked in the United Kingdom for dentistry (1st), medicine (2nd), and sports science (2nd) (Guardian University League Table 2021). 


\section{APPENDIX}

The individual human capital index $q_{i}$ of an individual $i$ is given by:

$$
\begin{aligned}
q_{i}= & -1.76+0.43 \ln (\mathrm{nb} . \text { of characters of the longest Wikipedia page }) \\
& +0.40 \ln (\mathrm{nb} . \text { of Wikipedia pages in different languages })+0.47 \ln (\mathrm{nb} . \text { of works in Worldcat }) \\
& +0.46 \ln (\mathrm{nb} . \text { of publication languages in Worldcat }) \\
& +0.47 \ln (\mathrm{nb} . \text { of library holdings in Worldcat })
\end{aligned}
$$

We assume that having no Wikipedia page is similar to having one page with a length of 60 characters and that having no Worldcat page is similar to having a page with one work in one language held by one library. The constant -1.76 normalizes $q_{i}$ at 0 when there is neither a Wikipedia page, nor a Worldcat page. The weights $(0.43,0.40$, etc) are obtained from the first principal component of the five indicators (De la Croix et al. 2020).

The notability $Q$ of a university aggregates the $q$ of the top 5 individuals who were active in the preceding 25 years using the following formula:

$$
Q=\sqrt{\sum_{i=1}^{5} \frac{1}{5}\left(\frac{q_{i}}{s_{i}}\right)^{2}}
$$

where $s_{i}$ is the number of universities at which $i$ had an appointment.

\section{ACKNOWLEDGMENTS}

This project has received funding from the European Research Council (ERC) under the European Union's Horizon 2020 research and innovation programme, under grant agreement No 883033 "Did elite human capital trigger the rise of the West? Insights from a new database of European scholars."

First version May 18, 2021. Updated December 16, 2021.

\section{REFERENCES}

Anderson, Peter John. 1893. Lists of Officers, University and King's College: Aberdeen, 1495-1860. Aberdeen: Aberdeen University Press.

De la Croix, David, Frédéric Docquier, Alice Fabre, and Robert Stelter. 2020. "The Academic Market and the Rise of Universities in Medieval and Early Modern Europe (1000-1800).” CEPR Discussion Paper 14509.

Herbermann, Charles George. 1913. The Catholic Encyclopedia. New York: Encyclopedia Press, Incorporated.

Rashdall, Hastings. 1895. The Universities of Europe in the Middle Ages. Oxford: Clarendon Press. 